\title{
PENGARUH JARAK TANAM TERHADAP PERTUMBUHAN PADI ADAN KRAYAN (Oryza sativa L.)
}

\section{(The Effect Of Row Spacing On The Growth Of Upland Rice Adan Krayan (Oryza sativa L.))}

\author{
Harfresen, Rustam Baraq Noor dan Iin Arsensi \\ Fakultas Pertanian, Universitas Widya Gama Mahakam Samarinda \\ Penulis koresponden : iinarsensi@uwgm.ac.id
}

Article Submitted: $26-03-2021$

Article Accepted: 26-05-2021

\begin{abstract}
Purpose of the research was to the effect of row spacing on the growth of upland rice (Oryza sativa L.) Adan Krayan; and to find row spacing for better growth of upland rice Adan Krayan.The research carried out from July to October 2020 in Liang Bua Village, Krayan Barat su-district, Nunukan Regency.The research used Completely Randomized Block Design (CRBD) with four treatment of row spacing and five replications namely : no uniform as control $(\mathrm{p} 0), 30$ $\mathrm{cm} \times 30 \mathrm{~cm}(\mathrm{p} 1), 40 \mathrm{~cm} \times 40 \mathrm{~cm}(\mathrm{p} 2)$, and $50 \mathrm{~cm} \times 50 \mathrm{~cm}(\mathrm{p} 3)$. Result of the research revealed that : (1) row spacing treatment affected significantly to very significantly on the plant height, number of leaf and number of tiller at 30,60, and 90 days after planting, and (2) the best of the growth was produced in $40 \mathrm{~cm} \times 40 \mathrm{~cm}$.
\end{abstract}

Keywords : Row Spacing, Adan Krayan Upland Rice

\section{PENDAHULUAN}

Tanaman padi (Oryza sativa L.) adalah tanaman pangan penting yang menjadi makanan pokok lebih dari setengah penduduk yang ada di dunia ini. Di Indonesia, padi merupakan komoditas utama dalam menyokong pangan masyarakat. Tantangan yang dihadapi Indonesia sebagai negara dengan jumlah penduduk yang besar adalah dalam memenuhi kebutuhan pangan penduduk. Oleh karena itu, kebijakan ketahanan pangan menjadi fokus utama dalam pembangunan pertanian.

Data Balai Pusat Statistik tahun 2020, bahwa produksi padi diperkirakan sebesar 55,16 juta ton GKG, hal ini mengalami kenaikan sebanyak 556,51 ribu ton atau 1,02 $\%$ dibandingkan produksi di tahun 2019 yang sebesar 54,60 juta ton GKG Jika potensi produksi padi pada 2020 dikonversikan menjadi beras untuk konsumsi pangan penduduk, produksi beras pada 2020 diperkirakan sebesar 31,63 juta ton, mengalami kenaikan sebanyak 314,10 ribu ton atau 1,00\% dibandingkan 2019 yang sebesar 31,31 juta ton.

Padi yang sudah diolah menjadi beras merupakan pangan utama bagi sebagian besar penduduk Indonesia. Meski sebagai bahan pangan utama padi dapat digantikan oleh bahan pangan lainnya sebagai penghasil karbohidrat seperti : ubi kayu, ubi jalar, kentang, jagung, gandum, sagu dan lain-lain. Akan tetapi, padi lebih banyak diminati atau lebih disukai dari pada jenis pangan lainnya. Apalagi saat ini sudah banyak riset dan percobaan dilakukan untuk menghasilkan tanaman padi dengan kualitas baik serta berumur pendek.

Padi Adan Krayan adalah padi lokal yang ditanam secara turun temurun oleh masyarakat suku Dayak pedalaman Kalimantan tepatnya di Kecamatan Krayan, Kabupaten Nunukan. Beras Adan Krayan 
yang terkenal pulen, legit, dan aromatik. Cita rasa Beras Adan Krayan tidak bisa ditemukan di wilayah lain. merupakan satu keunikan dan keunggulan tersendiri. Hal ini disebabkan oleh cara penanaman padi itu sendiri yang diolah secara organik dengan memanfaatkan kotoran kerbau sebagai input pemupukan. Sehingga merupakan satu keunikan dan keunggulan tersendiri. Menurut Martiolen (2018) dengan keunggulan yang dimiliki maka beras Adan Krayan ini menjadikannya sebagai sumber makanan pokok yang dikonsumsi secara luas di Malaysia dan Brunei Darussalam bahkan konon keluarga kerajaan Brunei Darussalam gemar mengkonsumsi Beras Adan Krayan.

Waktu yang dibutuhkan padi Adan Krayan sejak persemaian benih hingga panen sekitar lima sampai enam bulan (Evi, 2012). Produksi padi Adan Krayan belum tinggi, sebab setiap lahan persawahan hanya digarap sekali setahun. Oleh sebab itu, perlu ada teknologi inovatif budidaya sehingga dapat meningkatkan produksi padi Adan Krayan. Hingga saat ini petani belum memperoleh manfaat optimal dari komoditas padi tersebut. Pada umumnya petani masih terkendala pada upaya peningkatan produktivitas padi karena padi Adan Krayan merupakan jenis padi lokal yang masih rendah produksinya.

Beberapa riset dan penelitian telah dilakukan pada tanaman padi Adan Krayan salah satunya adalah jarak tanam. Jarak tanam berpengaruh terhadap pertumbuhan tanaman padi, karena berhubungan dengan persaingan antara sistem perakaran untuk mendapatkan makanan atau unsur hara dari dalam tanah. Jika kondisi tanah subur lebih dianjurkan menanam padi dengan menggunakan jarak tanam yang lebih pendek dibandingkan dengan tanah yang kurang subur. Optimasi penggunaan satuan luas tanah dapat diperoleh melalui penggunaan jarak tanam. Menurut Masdar (2005) bahwa pola tanam segi empat dengan jarak tanam 30x30 cm merupakan jarak tanam yang sering digunakan petani.
Jarak tanam juga merupakan salah satu faktor yang menentukan tinggi ataupun rendahnya produksi suatu pertanaman padi, selain itu pengaturan jarak tanam dipengaruhi oleh varietas padi dan kesuburan tanah. Menurut Muliasari (2009) bahwa variates padi yang memiliki kemampuan anakan yang tinggi membutuhkan jarak tanam lebih lebar jika dibandingkan dengan varietas yang memiliki daya anakan yang rendah.

Berdasarkan uraian diatas maka dilakukan penelitian dengan tujuan untuk mengetahui jarak tanam yang paling tepat untuk pertumbuhan tanaman padi Adan Krayan.

\section{METODE PENELITIAN}

\section{Tempat dan Waktu}

Penelitian dilaksanakan di lahan pertanian di Desa Liang Bua Kecamatan Krayan Barat Kabupaten Nunukan, selama 3 bulan dimulai dari bulan Juli 2020 sampai dengan Oktober 2020.

\section{Bahan dan Alat}

Bahan yang digunakan Benih Padi varietas Adan putih, kayu patok, papan label. MSG

Alat yang digunakan yaitu tali, cangkul, parang, meteran, camera, kalkulator, alat tulis-menulis,

\section{Rancangan Penelitian}

Penelitian ini menggunakan Rancangan Acak Kelompok (RAK) dengan faktor perlakuan tunggal dan lima ulangan yang terdiri atas empat taraf: jarak tanam tidak beraturan $(15 \mathrm{~cm}-20 \mathrm{~cm})(\mathrm{p} 0)$, jarak tanam $30 \mathrm{~cm}$ x $30 \mathrm{~cm}(\mathrm{p} 1)$, jarak tanam 40 $\mathrm{cm} \times 40 \mathrm{~cm}(\mathrm{p} 2)$, dan jarak tanam $50 \mathrm{~cm} \mathrm{x}$ $50 \mathrm{~cm}(\mathrm{p} 3)$. Secara keseluruhan terdapat 30 unit petak penelitian.

Penelitian ini menggunakan system tanam jajar legowo dengan petakan pertama menggunakan jarak tanam $30 \mathrm{~cm}$ x $30 \mathrm{~cm}$, petakan kedua menggunakan jarak tanam 40 $\mathrm{cm}$ x $40 \mathrm{~cm}$, petakan ketiga menggunakan jarak tanam $50 \quad \mathrm{~cm} \quad \mathrm{x} \quad 50 \mathrm{~cm}$. 


\section{Prosedur Penelitian}

1. Penyiapan lahan dan pembuatan petak penelitian. Penyiapan lahan dan pembuatan petak penelitian bertujuan untuk memberi batas petak/lahan yang akan digunakan dalam penelitian ini. Tali dan kayu digunakan sebagai patok pembatas petak atau lahan.

2. Penyemaian benih. Benih yang disiapkan untuk menjadi bibit direndam satu hari dua malam dan dikeringkan sampai akar muncul yang berwarna putih, setelah akar muncul maka benih padi tersebut akan di tabur di tempat penyemaian yang telah di sediakan, lama penyemaian selama satu bulan terhitung dari hari penaburan benih.

3. Penyemprotan semai menggunakan Mono Sodium Glutamat (MSG). Penyemprotan ini dilakukan 1 minggu sebelum semai dipindahkan ke lahan penelitian. Jumlah MSG yang digunakan 3 sendok makan dengan dilarutkan kedalam air sebanyak 15 liter. Penyemprotan MSG ini telah dilakukan secara turun temurun di masyarakat adat suku Dayak Krayan. MSG sendiri memiliki senyawa $\mathrm{C}, \mathrm{H}$, $\mathrm{O}, \mathrm{N}$ dan $\mathrm{Na}$ yang merupakan senyawa yang diperlukan sebagai nutrisi perkembangan tanaman.

4. Penanaman. Bibit yang sudah berumur satu bulan dipindahkan ke petakan yang sudah disediakan, penanamannya dilakukan dengan cara tradisonal atau menggunakan tenaga manusia (tanpa menggunakan mesin) dengan mengunakan tali yang telah direntangkan sesuai perlakuan jarak tanam.

5. Pemeliharaan. Pemeliharaan tanaman meliputi : (1) penyiangan gulma yang tumbuh disela-sela tanaman dengan cara mencabut gulma; dan (2) menjaga air di dalam petakan agar tidak terlalu kering dan tidak terlalu becek sehingga tanaman padi tidak mengalami kekeringan dan juga tidak teredam di dalam air.

\section{Pengamatan}

Pada setiap petak penelitian diambil $20 \%$ dari jumlah tanaman sebagai sampel, variabel pengamatan sebagai berikut:

\section{Tinggi Tanaman $(\mathrm{cm})$}

Pengukuran tinggi tanaman pada umur 30, 60, 90 hari setelah tanam dilakukan mulai dari $5 \mathrm{~cm}$ dari permukaan tanah hingga ujung daun paling panjang

2.Jumlah daun (helai)

Perhitungan jumlah daun pada umur 30 , 60, 90 hari setelah tanam dilakukan pada setiap rumpun tanaman sampel.

3.Jumlah anakan (buah)

Perhitungan jumlah anakan pada umur 30, 60, 90 hari setelah tanam dilakukan pada setiap rumpun tanaman sampel.

\section{Analisa Data}

Untuk mengetahui pengatuh perlakuan jarak tanam, data hasil pengamatan dianalisis dengan sidik ragam dan jika berpengaruh nyata atau berpengaruh sangat nyata, maka dilakukan uji lanjut dengan Uji beda Nyata Terkecil (BNT) $5 \%$.

\section{HASIL DAN PEMBAHASAN}

\section{Tinggi tanaman}

Hasil sidik ragam menunjukkan bahwa perlakuan jarak tanam berpengaruh sangat nyata terhadap tinggi tanaman pada umur 30, 60 dan 90 hari setelah tanam. Hasil penelitian pengaruh jarak tanam terhadap tinggi tanaman pada umur 30, 60 dan 90 hari setelah tanam disajikan pada Tabel 1. 
Tabel 1. Rata-rata Tinggi Tanaman Padi Adan Krayan (cm)

\begin{tabular}{lccc}
\hline \multicolumn{1}{c}{ Perlakuan Jarak } & \multicolumn{3}{c}{ Tinggi Tanaman pada Umur } \\
\cline { 2 - 4 } & $30 \mathrm{HST}$ & $60 \mathrm{HST}$ & $90 \mathrm{HST}$ \\
\hline $\begin{array}{l}\text { Hasil Sidik Ragam } \\
\text { Jarak Tanam Tidak }\end{array}$ & $* *$ & & \\
$\begin{array}{l}\text { Beraturan (p0) } \\
30 \mathrm{~cm} \times 30 \mathrm{xm}\end{array}$ & $30,36 \mathrm{~b}$ & $41,15 \mathrm{c}$ & $52,23 \mathrm{c}$ \\
$(\mathrm{p} 1)$ & & $71,66 \mathrm{a}$ & $108,46 \mathrm{a}$ \\
$40 \mathrm{~cm} \times 40 \mathrm{~cm}$ & $45,94 \mathrm{a}$ & $62,48 \mathrm{~b}$ & $95,20 \mathrm{~b}$ \\
$(\mathrm{p} 2)$ & $43,48 \mathrm{a}$ & & \\
$50 \mathrm{~cm} \times 50 \mathrm{~cm}$ & $44,37 \mathrm{a}$ & $60,40 \mathrm{~b}$ & $94,40 \mathrm{~b}$ \\
$(\mathrm{p} 3)$ & & & \\
\hline
\end{tabular}

Keterangan : Angka rata-rata yang dikuti dengan huruf yang sama adalah berbeda tidak nyata berdasarkan uji BNT taraf 5\%.

Berdasarkan hasil uji BNT 5\% menunjukkan bahwa perlakuan berbagai jarak tanam $30 \times 30 \mathrm{~cm}(\mathrm{p} 1), 40 \times 40 \mathrm{~cm}$ (p2) dan $50 \times 50 \mathrm{~cm}$ (p3) berbeda nyata dibandingkan dengan perlakuan jarak tanam tidak beraturan $(\mathrm{p} 0)$. Tanaman paling tinggi pada umur 30, 60 dan 90 hari setelah tanam dihasilkan pada perlakuan jarak tanam $30 \mathrm{x}$ $30 \mathrm{~cm}(\mathrm{p} 1)$ yaitu berturut-turut 45,94 cm, $71,66 \mathrm{~cm}$ dan $108,46 \mathrm{~cm}$, sedangkan yang paling rendah dihasilkan pada jarak tanam tidak beraturan (p0) yaitu berturut-turut $30,36 \mathrm{~cm}, 41,15 \mathrm{~cm}$, dan $52,23 \mathrm{~cm}$. Hal ini disebabkan karena pertambahan tinggi tanaman padi Adan Krayan dipengaruhi oleh jarak tanam yang tidak terlalu renggang sehingga terjadi persaingan antara tanaman dalam memperoleh unsur hara dan cahaya matahari untuk melakukan proses fotosintesis. Pertumbuhan adalah proses dalam kehidupan tanaman yang mengakibatkan perubahan ukuran dan tinggi. Pertumbuhan suatu tanaman ditentukan oleh beberapa faktor-faktor. Dalam hal ini ada dua faktor penting yang berpengaruh pada pertumbuhan tanaman padi Adan Krayan, yaitu faktor genetik dan faktor lingkungan.

Menurut Nursanti (2009) bahwa pertambahan tinggi tanaman ini disebabkan karena tajuk tanaman yang semakin rapat mengakibatkan kualitas cahaya yang diterima menjadi menurun. Semakin rapat jarak tanam padi Adan Krayan maka pertumbuhan tinggi tanaman akan semakin cepat karena tanaman saling bersaing berusaha mencari sinar matahari yang lebih banyak.

Tanaman padi Adan Krayan yang tumbuh baik mampu menyerap unsur hara dalam jumlah banyak dari dalam tanah, ketersediaan hara dalam tanah berpengaruh terhadap aktivitas tanaman termasuk aktivitas fotosintesis, sehingga dengan demikian tanaman dapat meningkatkan pertumbuhan dan produksi.

\section{Jumlah daun}

Hasil sidik ragam menunjukkan bahwa perlakuan jarak tanam berpengaruh nyata terhadap jumlah daun pada umur 30 hari setelah tanam; berpengaruh sangat nyata terhadap jumlah daun pada umur 60 dan 90 hari setelah tanam. Hasil penelitian pengaruh jarak tanam terhadap jumlah daun pada umur 30, 60 dan 90 hari setelah tanam disajikan pada Tabel 2 . 
Tabel 2. Rata-rata Jumlah Daun Tanaman Padi Adan Krayan (Helai)

\begin{tabular}{lccc}
\hline Perlakuan Jarak & \multicolumn{3}{c}{ Jumlah Daun pada Umur } \\
\cline { 2 - 4 } Tanam & $30 \mathrm{HST}$ & $60 \mathrm{HST}$ & $90 \mathrm{HST}$ \\
\hline $\begin{array}{l}\text { Hasil Sidik Ragam } \\
\text { Jarak Tanam Tidak }\end{array}$ & $*$ & & \\
$\begin{array}{l}\text { Beraturan (P0) } \\
30 \mathrm{~cm} \times 30 \mathrm{xm}\end{array}$ & $12,40 \mathrm{~b}$ & $24,35 \mathrm{c}$ & $42,17 \mathrm{c}$ \\
$(\mathrm{p} 1)$ & $19,34 \mathrm{a}$ & $68,36 \mathrm{~b}$ & $79,10 \mathrm{~b}$ \\
$\begin{array}{l}40 \mathrm{~cm} \times 40 \mathrm{~cm} \\
(\mathrm{p} 2)\end{array}$ & $19,76 \mathrm{a}$ & $103,28 \mathrm{a}$ & $113,56 \mathrm{a}$ \\
$50 \mathrm{~cm} \times 50 \mathrm{~cm}$ & $18,40 \mathrm{a}$ & $90,15 \mathrm{a}$ & $93,05 \mathrm{a}$ \\
$(\mathrm{p} 3)$ & & & \\
\hline
\end{tabular}

Keterangan : Angka rata-rata yang dikuti dengan huruf yang sama adalah berbeda tidak nyata berdasarkan uji BNT taraf 5\%.

Berdasarkan hasil uji BNT 5\% menunjukkan bahwa perlakuan berbagai jarak tanam $30 \times 30 \mathrm{~cm}(\mathrm{p} 1), 40 \times 40 \mathrm{~cm}$ (p2) dan $50 \times 50 \mathrm{~cm}$ (p3) berbeda nyata dibandingkan dengan perlakuan jarak tanam tidak beraturan $(\mathrm{p} 0)$. Jumlah daun paling banyak pada umur 30, 60 dan 90 hari setelah tanam dihasilkan pada perlakuan jarak tanam $40 \times 40 \mathrm{~cm}(\mathrm{p} 2)$ yaitu berturut-turut 19,76 helai, 103,28 helai dan 113,56 helai, sedangkan yang paling sedikit dihasilkan pada jarak tanam tidak beraturan ( $\mathrm{p} 0$ ) yaitu berturut-turut 12,40 helai, 24,35 helai, dan 42,17 helai.

Dari hasil sidik ragam menunjukkan bahwa perlakuan jarak tanam sangat berpengaruh nyata terhadap pertumbuhan padi Adan Krayan dibandingkan dengan cara penanaman yang telah dilakukan secara turun temurun oleh masyarakat adat suku Dayak Krayan, dimana cara menanamnya tidak beraturan atau penanamannya sejangkauan petani dan jarak tanamnya tidak menentu ada yang sangat dekat, dan ada juga yang renggang sehingga pemanfaatan lahan juga tidak maksimal. Perlakuan jarak tanam $40 \mathrm{~cm} \times 40 \mathrm{~cm}$, terlihat bahwa pertumbuhan dan jumlah helai daunnya sangat signifikan pertambahannya. Hal ini menunjukkan bahwa jumlah daun yang banyak akan memudahkan tanaman untuk melakukan fotosintesis. Seperti yang dinyatakan oleh Prawitasari (2003) bahwa pertumbuhan dan perkembangan organ tanaman ditentukan oleh suatu proses yang dinamakan fotosintesis. Daun sebagai organ vital bagi tanaman tempat berlangsungnya proses fotosintesis dimana pembentukan daun baru dapat meningkatkan jumlah daun pertanaman/rumpun pada tanaman padi Adan Krayan sehingga hasil produksi padi juga meningkat.

\section{Jumlah anakan}

Hasil sidik ragam menunjukkan bahwa perlakuan jarak tanam berpengaruh nyata terhadap jumlah anakan pada umur 30 hari setelah tanam; berpengaruh sangat nyata terhadap jumlah anakan pada umur 60 dan 90 hari setelah tanam. Hasil penelitian pengaruh jarak tanam terhadap jumlah anakan pada umur 30, 60 dan 90 hari setelah tanam disajikan pada Tabel 3. 
Tabel 3. Rata-rata Jumlah Anakan Tanaman Padi Adan Krayan (buah)

\begin{tabular}{lccc}
\hline Perlakuan Jarak & \multicolumn{3}{c}{ Jumlah Anakan pada Umur } \\
\cline { 2 - 4 } Tanam & $30 \mathrm{HST}$ & $60 \mathrm{HST}$ & $90 \mathrm{HST}$ \\
\hline $\begin{array}{l}\text { Hasil Sidik Ragam } \\
\text { Jarak Tanam Tidak }\end{array}$ & $*$ & & \\
$\begin{array}{l}\text { Beraturan (P0) } \\
30 \mathrm{~cm} \times 30 \mathrm{xm}\end{array}$ & $3,69 \mathrm{~b}$ & $10,48 \mathrm{c}$ & $14,63 \mathrm{c}$ \\
$(\mathrm{p} 1)$ & $7,22 \mathrm{a}$ & $20,58 \mathrm{~b}$ & $20,66 \mathrm{~b}$ \\
$\begin{array}{l}40 \mathrm{~cm} \times 40 \mathrm{~cm} \\
(\mathrm{p} 2)\end{array}$ & $8,08 \mathrm{a}$ & $31,64 \mathrm{a}$ & $30,08 \mathrm{a}$ \\
$50 \mathrm{~cm} \times 50 \mathrm{~cm}$ & $6,35 \mathrm{a}$ & $28,75 \mathrm{a}$ & $30,15 \mathrm{a}$ \\
$(\mathrm{p} 3)$ & & & \\
\hline
\end{tabular}

Keterangan : Angka rata-rata yang dikuti dengan huruf yang sama adalah berbeda tidak nyata berdasarkan uji BNT taraf 5\%.

Berdasarkan hasil uji BNT 5\% menunjukkan bahwa jumlah anakan padi Adan Krayan pada perlakuan berbagai jarak tanam $30 \times 30 \mathrm{~cm}(\mathrm{p} 1), 40 \times 40 \mathrm{~cm}(\mathrm{p} 2)$ dan $50 \times 50 \mathrm{~cm}(\mathrm{p} 3)$ berbeda nyata dibandingkan dengan perlakuan jarak tanam tidak beraturan (p0). Jumlah anakan paling banyak pada umur 30 dan 60 hari setelah tanam dihasilkan pada perlakuan jarak tanam $40 \times 40 \mathrm{~cm}(\mathrm{p} 2)$ yaitu berturut-turut 8,08 anakan dan 31,64 anakan dan paling umur 90 hari setelah dihasilkan pada perlakuan 50 x $50 \mathrm{~cm}$ (p3) yaitu 30,15 anakan, sedangkan yang paling sedikit dihasilkan pada jarak tanam tidak beraturan (p0) yaitu berturut-turut 3,69 anakan, 10,48 anakan, dan 14,63 anakan. Hal ini disebabkan karena jarak tanam tertentu yaitu $50 \mathrm{~cm}$ x $50 \mathrm{~cm}$ dapat meningkatkan jumlah anakan yang lebih banyak, dibandingkan dengan cara penanaman yang digunakan oleh petani suku Dayak setempat dimana mereka menanam tidak menggunakan jarak tanam. Jarak tanam $50 \mathrm{~cm}$ x $50 \mathrm{~cm}$ memberikan ruang pertumbuhan yang lebih baik bagi pertambahan jumlah anakan padi Adan Krayan per rumpun. Sebab jarak tanam yang rapat dan tidak beraturan dapat menghambat pertumbuhan anakan padi Adan Krayan. Jarak tanam yang rapat dan tidak beraturan akan menyebabkan persaingan akan ruang tumbuh karena daun tanaman padi Adan Krayan akan saling berhimpitan atau menaungi sehingga sinar matahari tidak maksimal diterima oleh daun. Jarak tanam juga dapat mempengaruhi penyerapan unsur hara dari dalam tanah sehingga dapat mengakibatkan pembentukan klorofil pada daun terganggu. Hal ini seperti yang diungkapkan oleh Masdar, dkk.(2006) bahwa jarak tanaman yang rapat dapat mengakibatkan vigor mengalami stress sehingga perkembangan anakan terhambat. Menurut Sulistiani (2009) bahwa jarak tanam padi yang cukup longgar akan memberi keleluasaan pertumbuhan anakan padi, sinar matahari maksimal diterima semua daun untuk berfotosintesis, Jumlah anakan produktif merupakan salah satu komponen agronomis yang berpengaruh terhadap hasil panen padi (produktivitas). Salah satu cara untuk mendapatkan pertumbuhan jumlah anakan padi Adan Krayan yang terbaik adalah dengan mengatur jarak tanam $50 \mathrm{~cm}$ x $50 \mathrm{~cm}$, karena persaingan dalam memperoleh ruang tumbuh, unsur hara dan mineral dari dalam tanah, air dan radiasi matahari diantara tanaman padi Adan Krayan menjadi lebih rendah.

Husna (2010) menyatakan bahwa jumlah anakan akan maksimal apabila tanaman memiliki sifat genetik yang baik ditambah dengan keadaan lingkungan yang menguntungkan atau sesuai dengan pertumbuhan dan perkembangan tanaman. 


\section{KESIMPULAN DAN SARAN}

\section{Kesimpulan}

Berdasarkan analisis dan pembahasan dapat disimpulkan yaitu sebagai berikut :

1. Perlakuan jarak tanam berpengaruh nyata sampai sangat nyata terhadap tinggi tanaman, jumlah daun, dan jumlah anakan padi Adan Krayan.

2. Perlakuan jarak tanam $40 \mathrm{~cm} \times 40 \mathrm{~cm}$ (p2) menghasilkan jumlah daun dan jumlah anakan yang lebih banyak dibandingkan perlakuan jarak tanam yang lain.

\section{Saran}

Berdasarkan hasil penelitian dapat dikemukakan beberapa saran yaitu :

1. Untuk budidaya tanaman padi Adan Krayan dianjurkan menggunakan jarak tanam $40 \mathrm{~cm} \times 40 \mathrm{~cm}$.

2. Perlu dilakukan penelitian lanjutan dengan berbagai kombinasi perlakuan pemupukan (organik, anorganik) baik melalui akar maupun daun.

\section{DAFTAR PUSTAKA}

Evi, I. 2012. Beras Adan Krayan.http://eviindarwanto.com.

Diakses pada tanggal 01 Maret 2021

Husna, Y. 2010. Pengaruh penggunaan jarak tanam terhadap pertumbuhan dan produksi padi sawah (Oryza sativa L) varietas IR 42 dengan metode SRI (system of rice intensification). J. jurusan agroteknologi. Fakultas pertanian. Universitas Riau. Diakses pada 19 Januari 2021.

Martiolen,. 2018. Studi tentang Kebijakan Pemerintah Kecamatan dalam Upaya Swasembada Beras Adan di Kecamatan Krayan. eJournal Pemerintahan Integratif, 2018, 6(1):
11-20ISSN: $2337-8670$ (online), ISSN 2337-8662 (print), ejournal.pin.or.id. Diakses pada 19 Januari 2021.

Masdar . 2005. Pengaruh Jumlah Bibit Per Titik Tanam dan Umur Bibit Terhadap Pertumbuhan Reproduktif $\mathrm{T}$ anaman Padi Pada Irigasi Tanpa Penggenangan. Jurnal Dinamika Pertanian,21(2):121-126. Didalam Website :https://ejournal.unida.gonto r.ac.id/index.php/agrotech/article/vie wFile/898/835. Diakses pada 5 Maret 2020

Muliasari, A. A. 2009. Optimasi Jarak Tanam dan Umur Bibit pada Padi Sawah (Oryza sativa L). Skripsi. Institut Pertanian Bogor. 76 hal. Dalam

website :https://scholar.google.co.id/ scholar?hl=id\&as_sdt $=0 \% 2 \mathrm{C} 5 \& \mathrm{q}=\mathrm{d}$ aftar+pustaka+Muliasari\%2C+2009 \&btnG=. Diakses pada 5 Maret 2020

Masdar, Musliar K, Bujang R, Nurhajati H, dan Helmi. 2006. Tingkat hasil dan komponen hasil system intensifikasi padi (SRI) tanpa pupuk organik di daerah curah hujan tingi. ( dikutip dalam jurnal Nur magfiro,Iskandar M.Lapanjang, Usman Made 2017 ) diakses pada 19 Januari 2021.

Nursanti, R. 2009. Pengaruh Umur Bibit dan Jarak Tanam Terhadap Pertumbuhan dan Produktivitas Tanaman Buru Hotong (Setaria italica (L.) Beauv). Skripsi. Program Studi Agronomi. Fakultas Pertanian. Institut Pertanian Bogor. 
Hal 27 -28. Tidak dipublikasikan. diakses pada tanggal 19-Januari2021

Prawitasari, T. 2003. Siknal Fisiologi Pada Transisi ke Pertumbuhan Perkembangan Reproduktif. P2KSDM, Bogor (diakses pada 26 januari 2021)

Sulistiani, R., 2009. Efek jarak tanam terhadap interaksi hara dan mikroba pada pertumbuhan padi sawah $\begin{array}{lll}\text { (Oryza sativa } & \text { L.). } & \text { Sekolah }\end{array}$ Pascasarjana USU Medan Diakses pada 26 Januari 2021 